\title{
Tree water relations can trigger monoterpene emissions from Scots pine stems during spring recovery
}

\author{
A. Vanhatalo ${ }^{1}$, T. Chan ${ }^{1}$, J. Aalto ${ }^{1,2}$, J. F. Korhonen ${ }^{1}$, P. Kolari ${ }^{3}$, T. Hölttä ${ }^{1}$, E. Nikinmaa ${ }^{1}$, and J. Bäck ${ }^{1}$ \\ ${ }^{1}$ Department of Forest Sciences, University of Helsinki, Helsinki, Finland \\ ${ }^{2}$ SMEAR II station, University of Helsinki, Helsinki, Finland \\ ${ }^{3}$ Department of Physics, University of Helsinki, Helsinki, Finland
}

Correspondence to: A. Vanhatalo (anni.vanhatalo@helsinki.fi)

Received: 29 April 2015 - Published in Biogeosciences Discuss.: 22 May 2015

Accepted: 28 August 2015 - Published: 17 September 2015

\begin{abstract}
Tree canopies are known to emit large amounts of VOCs (volatile organic compounds) such as monoterpenes into the surrounding air. High VOC emission rates from boreal forests have been observed during the transition from winter to summer activity. The most important sources of these are considered to be the green foliage, understory vegetation and soil organisms, but emissions from the living stand woody compartments have so far not been quantified. We analyzed whether the non-foliar components could partially explain the springtime high emission rates. We measured the monoterpene emissions from Scots pine (Pinus sylvestris L.) stem and shoots during the dehardening phase of trees in field conditions in two consecutive springs. We observed a large, transient monoterpene burst from the stem, while the shoot monoterpene emissions remained low. The burst lasted about $12 \mathrm{~h}$. Simultaneously, an unusual nighttime sap flow and a non-systematic diurnal pattern of tree diameter were detected. Hence, we suggest that the monoterpene burst was a consequence of the recovery of the stem from wintertime, and likely related to the refilling of embolized tracheids and/or phenological changes in the living cells of the stem. This indicates that the dominant processes and environmental drivers triggering the monoterpene emissions are different between the stem and the foliage.
\end{abstract}

\section{Introduction}

The stems of mature coniferous trees contain significant quantities of oleoresin; 20-50\% per weight of the conifer oleoresin consists of monoterpenes (Langenheim, 2003), and the monoterpene content of Scots pine (Pinus sylvestris L.) wood is about $0.5 \%$ (from dry weight; Strömvall and Petersson, 2000). In addition to the volatile monoterpenes, oleoresin is composed of volatile sesquiterpenes and non-volatile diterpene acids. The composition and quantity of wood oleoresin depends on, e.g., tree species, age, provenance, health status, and environmental conditions (Back and Ekman, 2000; Erbilgin and Colgan, 2012), and is likely linked to protection against stem-damaging herbivores (Lewinsohn et al., 1991; Philips and Croteau, 1999; Trapp and Croteau, 2001). Oleoresin flows out from a mechanically damaged site to protect the tree by sealing the wound. Once in contact with air, the volatile parts of oleoresin evaporate, and the residual compounds harden to make a solid protective seal over damaged tissues. Yet, a fraction of the volatile part may react already on the oleoresin and form large polymers of low volatility.

It is well known that the foliage of conifers also contains several volatile isoprenoids (isoprene, monoterpenes, sesquiterpenes) as well as small oxygenated carbonyls, e.g., methanol, acetone and acetaldehyde, which are emitted at very variable rates (e.g., Isidorov et al., 1985; Christensen et al., 2000; Grabmer et al., 2004). Temperature is the main controlling factor for monoterpene emission, influencing their volatility in an exponential manner (Tingey et al., 1980), although recently light-dependent emissions from shoots have also been reported (Loreto et al., 1996; Staudt and Bertin, 1998; Shao et al., 2001; Tarvainen et al., 2005; Ghirardo et al., 2010), indicating a close dependence on carbon assimilation. Emissions of monoterpenes from tree 
canopies have a typical seasonal pattern, normally peaking in summer (e.g., Hakola et al., 2006).

Surprisingly, despite abundant knowledge on emissions of volatile isoprenoids from foliage, very little is known about their emissions from woody plant tissue. From the viewpoint of the timber and paper industry, isoprenoid emissions from harvested and further-processed timber have been previously reported (Strömvall and Petersson, 1991, 1993; Granström, 2007), but living woody tree parts have gained only little attention. As the oleoresin storage pools in stems are large, emissions occur constitutively without any damage to the tree itself, but their seasonal patterns or driving factors have not been studied in detail.

Resin duct network and water transport system are both pressurized systems: resin is under positive pressure caused by cells surrounding the ducts and xylem water under negative pressure caused by the transpiration created tension linking the pressure to many physiological processes of a tree. Apart from transpiration, the water status in a stem is linked to repeated freezing and thawing cycles in winter. These can cause embolism in water-conducting tracheids (Sperry, 1993), potentially hindering the stem water transport as transpiration commences at spring recovery of the canopy. Thus, one requirement for trees living in cold environments is that the xylem conduits are refilled and the water transport capacity recovers in the spring (e.g., Améglio et al., 2002). The water pressure changes in xylem and phloem can be reflected in the radial changes of inner bark and xylem (e.g., Mencuccini et al., 2013).

Interestingly, emissions from intact Scots pine branches can be very high in early spring, in many cases much higher than those later in the growing season (e.g., Tarvainen et al., 2005; Hakola et al., 2006). This implies that other factors related to the tree physiological processes in spring may also influence inherent emission rates, beyond the simple physical factors related to volatilization of VOCs or the factors related to biotic or abiotic damage.

To analyze the dynamics of stem monoterpene emissions and their possible relationship with the stem physiology in spring, we measured the emissions from a Scots pine stem during two springs in field conditions in a boreal pine forest. In addition, we measured sap flow, stem radial variation and foliage gas exchange (including emissions of monoterpenes) from the same tree. Our hypothesis was that the emissions from the stem are driven by several factors: one is related to incident changes in temperature (affecting volatilization), and the second one represents the dynamic emission driven by tree physiological processes. The latter one was expected to be linked to tree water relations, and thus the onset of monoterpene emissions from the stem in spring could be related to the recovery of tree water transport capacity.
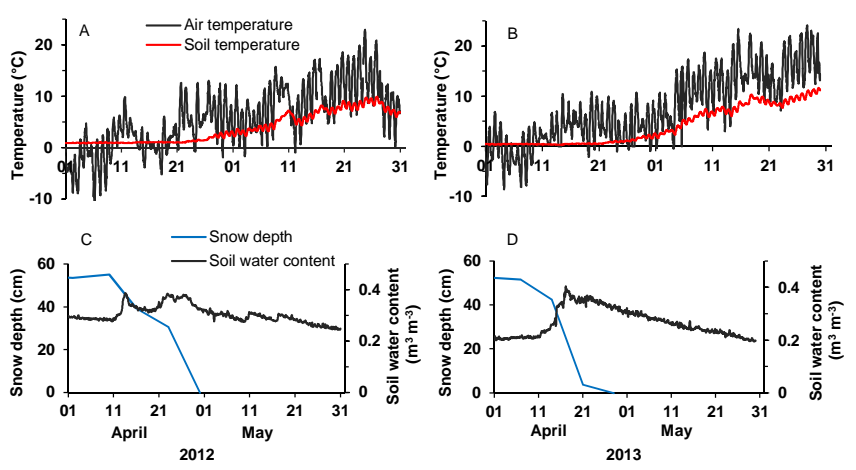

Figure 1. (a-b) Temperature at $8.4 \mathrm{~m}$ in air and in the soil A horizon $\left({ }^{\circ} \mathrm{C}\right)$. (c-d) Weekly snow depth $(\mathrm{cm})$ and volumetric soil water content in the A horizon $\left(\mathrm{m}^{3} \mathrm{~m}^{-3}\right)$. Left-hand panels are for AprilMay 2012 and right-hand panels for April-May 2013.

\section{Materials and methods}

Measurements were done at the SMEAR II (Station for Measuring Forest Ecosystem-Atmosphere Relations, $61^{\circ} 51^{\prime} \mathrm{N}$, $24^{\circ} 17^{\prime}$ E) stand (Hari and Kulmala, 2005) in 2012 and 2013. The growing season ranges, on average, from the end of April to mid-October (Table 1). Thermal spring, defined as a period when daily mean temperature stays between 0 and $10^{\circ} \mathrm{C}$, starts typically during the first half of April (Table 1). The growing season starts when snow has melted on open sites and mean daily air temperature rises above $5{ }^{\circ} \mathrm{C}$; this takes place around the turn from April to May. The ambient air temperature, snow depth and soil water content during the measurement periods in April-May 2012 and 2013 are shown in Fig. 1.

The measurement site is situated at the boreal vegetation zone in southern Finland. The stand is dominated by Scots pine with some Norway spruce (Picea abies (L.) Karst.), European aspen (Populus tremula L.), and birches (Betula spp.) as a mixture. The ground is covered with dwarf shrubs (Vaccinium myrtillus L., Vaccinium vitis-idaea L.) and mosses (Pleurozium schreberi (Brid.) Mitt., Dicranum spp.). Soil is haplic podzol formed from glacial till and its thickness on bedrock is quite low, on average only $0.5-0.7 \mathrm{~m}$.

The tree-scale parameters were measured from a visibly healthy, representative Scots pine ca. 50-year old individual belonging to the dominating canopy layer. This tree was $18.6 \mathrm{~m}$ tall and had a diameter of $20 \mathrm{~cm}$ at breast height (in 2012), and has been measured for diameter change and sap flow since 2005. The lowest living branches grew at a height of $10 \mathrm{~m}$. The shoots and stem were inspected visually, and no injuries or other abnormalities could be seen before or after the installation of measurement device.

The gas exchange of the stem was measured with a transparent enclosure (see below). The flux calculation of stem enclosure data was done according to Kolari et al. (2009). The top-canopy shoot gas exchange was measured at the height of 
Table 1. Environmental variables at the study site during the statistical period 1981-2010 and in studied years 2012 and 2013.

\begin{tabular}{|c|c|c|c|}
\hline & $1981-2010^{\mathrm{a}}$ & $2012^{b}$ & $2013^{c}$ \\
\hline Annual mean air temperature, ${ }^{\circ} \mathrm{C}$ & 3.5 & 3.3 & 4.9 \\
\hline Minimum air temperature, ${ }^{\circ} \mathrm{C}$ & -38.1 & -31.7 & -29.5 \\
\hline \multirow{3}{*}{ Maximum air temperature, ${ }^{\circ} \mathrm{C}$} & (January 1987) & (4 February) & (18 January) \\
\hline & 33.1 & 27.5 & 29.6 \\
\hline & (July 2010) & (29 July) & (26 June) \\
\hline Annual precipitation, $\mathrm{mm}$ & 711 & 907 & 615 \\
\hline Annual maximum snow depth, $\mathrm{cm}$ & 43 & 76 & 68 \\
\hline Duration of snow cover, days & 227 & 157 & 179 \\
\hline First snow ${ }^{\mathrm{c}}$ & 15 October & 28 November & 26 October \\
\hline Snowmelt & 15-30 May & 4 May & 24 April \\
\hline Thermal spring start & 5 April & 10 April & 12 April \\
\hline Start of the growing season & 27 April-2 May & 25 April & 27 April \\
\hline Annual cumulative temperature sum, degree days & $1200-1300$ & 1161 & 1388 \\
\hline April mean temperature, ${ }^{\circ} \mathrm{C}$ & 2.3 & 1.5 & 1.7 \\
\hline April minimum temperature, ${ }^{\circ} \mathrm{C}$ & -19.7 & -16.5 & -14.5 \\
\hline April maximum temperature, ${ }^{\circ} \mathrm{C}$ & 23.4 & 13.9 & 11.9 \\
\hline April precipitation, $\mathrm{mm}$ & 37 & 60 & 42 \\
\hline May mean temperature, ${ }^{\circ} \mathrm{C}$ & 8.9 & 9.4 & 12.2 \\
\hline May minimum temperature, ${ }^{\circ} \mathrm{C}$ & -7.1 & -2.9 & -2.7 \\
\hline May maximum temperature, ${ }^{\circ} \mathrm{C}$ & 28.2 & 23.8 & 24.9 \\
\hline May precipitation, mm & 45 & 56 & 16 \\
\hline
\end{tabular}

${ }^{a}$ Statistical data for years 1981-2010 are collected from Pirinen et al. (2012) and from Finnish Meteorological Institute (FMI) webpages (2014). ${ }^{\mathrm{b}}$ Data from FMI open-access data. ${ }^{\mathrm{c}}$ Date in the previous year.

about $17 \mathrm{~m}$ with a dynamic enclosure (including the two to three most recent needle year classes) as presented by Aalto et al. (2014). The shoot gas exchange was calculated as in Kolari et al. (2012) with a transpiration correction as in Altimir et al. (2006). Until the end of April 2013 the $\mathrm{H}_{2} \mathrm{O}$ and $\mathrm{CO}_{2}$ exchange was measured with URAS 4 infrared light absorption gas analyzers (Hartman and Braun, Frankfurt am Main, Germany), and from May 2013 onwards with a Li840A analyzer (Li-Cor, Lincoln, NE, USA). The replacement of the gas analyzers did not cause any irregularity in the $\mathrm{H}_{2} \mathrm{O}$ and $\mathrm{CO}_{2}$ exchange data because the calculation of gas exchange is primarily dependent on concentration difference instead of absolute concentration, and besides that, both analyzers were also calibrated for $\mathrm{CO}_{2}$ using a comparable calibration method and standard gases containing ca. ambient concentration of $\mathrm{CO}_{2}$. For more details on the $\mathrm{CO}_{2}$ and $\mathrm{H}_{2} \mathrm{O}$ calibration protocol used at SMEAR II, see Keronen et al. (2014). The stem $\mathrm{CO}_{2}$ efflux was temperature-normalized using the air temperatures measured inside the enclosure to study linkages with other stem processes by fitting an exponential curve to measurements at above-zero temperatures in April. Simple exponential models derived from the described plot (Eqs. 1 and 2) were then used to estimate $\mathrm{CO}_{2}$ efflux anomalies. The exponential models for respiration $(R)$ as a function of ambient temperature $(T)$ were

$R=4.5784 \cdot \exp (0.0925 \cdot T)$ and

$R=0.9874 \cdot \exp (0.207 \cdot T)$

for April 2012 and April 2013, respectively. The VOC emissions were measured online with a proton transfer reaction quadrupole mass spectrometer (PTR-Q-MS, Ionicon, Innsbruck, Austria; Hansel et al., 1995) modified from the system described in Ruuskanen et al. (2005). The description and accuracy of the VOC measurement system has been reported in Kolari et al. (2012). Altogether, ten protonated mass ions $(\mathrm{amu}+1)$ were monitored, but for this study we use data only on the $m / z 137$, which corresponds in Scots pine emissions mainly to monoterpenes. The other masses show such low signal-to-noise ratios and dependence on air humidity that their fluxes are insufficiently quantified. Calibrations of the PTR-Q-MS were carried out 2-3 times a month according to the method described in Taipale et al. (2008). A mixture of several VOCs (e.g., $\alpha$-pinene as a representative of monoterpenes) in nitrogen was used as a gas standard. The mixture was further diluted with volatile-free air from a zero air generator to attain concentrations below 20 parts per billion by volume, i.e., around the ambient atmospheric concentrations. The gaps in the data originate from the momentary maintenance and malfunction of the measuring system. As the temperature variation in springtime is wide, the measured emissions were normalized to enable better compari- 
son by applying the temperature normalization equation according to Guenther (1997) using an empirical beta coefficient of $0.09^{\circ} \mathrm{K}^{-1}$ and a standard temperature of $303.15 \mathrm{~K}$ according to Eq. (1):

$E_{0}=E \cdot \exp \left(\beta \cdot\left[T_{\mathrm{S}}-T\right]\right)$

where $E_{0}$ is the normalized emission rate $\left(\mathrm{ng} \mathrm{m}^{-2} \mathrm{~s}^{-1}\right), \mathrm{E}$ is the observed emission $\left(\mathrm{ng} \mathrm{m}^{-2} \mathrm{~s}^{-1}\right), \beta=0.09\left(\mathrm{~K}^{-1}\right), T_{\mathrm{S}}$ is the standard temperature $(\mathrm{K})$, and $\mathrm{T}$ is the temperature in chamber $(\mathrm{K})$.

The stem enclosure (Fig. 2) was designed specifically for measuring reactive gases with materials chemically inert to many VOCs to avoid detrimental signal losses. The enclosure covered $396 \mathrm{~cm}^{2}$ of the pine stem at the height of $12 \mathrm{~m}$ from the ground, which is close to the lowest living branches. The enclosure consists of a transparent and UV-permeable FEP foil $(0.05 \mathrm{~mm}$ thick, Fluorplast, Maalahti, Finland $)$ wrapped around the stem 2-3 times and tightened with binds on both ends. The vertical seal of the foil was made with FEP tape. Within the enclosure, a spiral of polyethylene-coated aluminum tube (Synflex, Eaton, USA) was wrapped around the stem to maintain an air space between the foil and the bark, and a FEP tape-covered aluminum brace for inlet and outlet connectors was placed between the spiral and the foil. Inside the enclosure, temperature was recorded with a copperconstantan thermocouple on the south-facing side of the stem. Rain water flow along the stem was blocked with a rain cover above the enclosure. Mounting of the enclosure was done well before the first measurements and without damaging the bark to avoid possible induced emissions. The bark at this height was rather smooth, so no levelling with a knife was needed. The measurements were done in steady state when the flow rate through the enclosure was about $1 \mathrm{~L} \mathrm{~min}^{-1}$. The sampling time for emissions was $2 \mathrm{~min} 45 \mathrm{~s}$, and samples were taken 24 times per day. To avoid accumulation of gases inside the enclosure, the enclosure was flushed between the samplings with above-canopy air at a rate of about $0.4 \mathrm{~L} \mathrm{~min}^{-1}$. All the monoterpene emissions from the stem are expressed per $\mathrm{m}^{2}$ of bark area and the emissions from the shoot per $\mathrm{m}^{2}$ of all-sided needle area. The stem area was defined as a smooth cylinder surface ignoring the cracks of the bark.

Changes in stem radius were measured with two linear variable displacement transducers (point dendrometers; LVDT; model AX/5.0/S, Solartron Inc., West Sussex, UK), at a height of $15 \mathrm{~m}$ from the base of the sample tree. The point dendrometers were installed on a rectangular stainless steel frame and were affixed onto the stem using two attachment plates. A detailed description of the dendrometers is provided by Sevanto et al. (2005). The head of the first dendrometer rested against a screw that was placed $10 \mathrm{~mm}$ through the bark surface, measuring xylem radial thickness $\left(d_{\mathrm{x}}\right)$. The head of the second dendrometer rested against the inner bark, which was exposed by incising the outer bark $3-4 \mathrm{~mm}$ deep

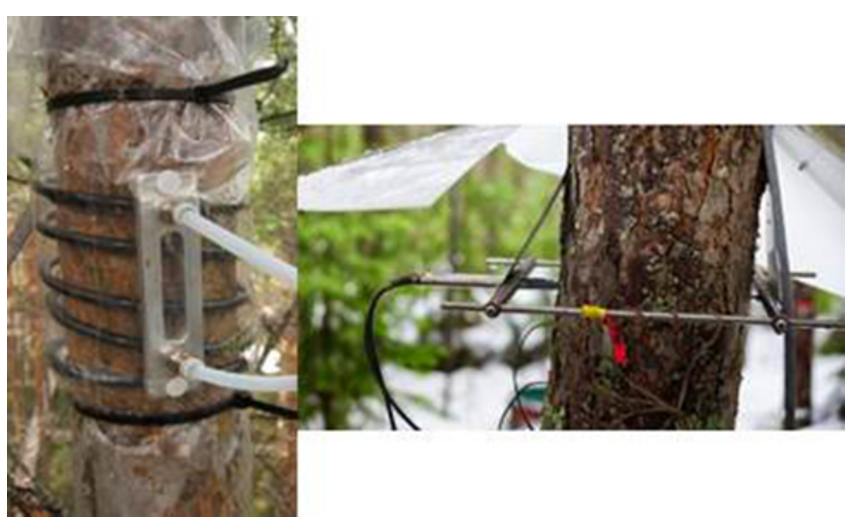

Figure 2. The stem enclosure around a Scots pine stem at a height of $12 \mathrm{~m}$ (left) and a linear variable displacement transducer to measure stem radius changes (right).

with a scalpel. This dendrometer measured whole-stem radial thickness $\left(d_{\mathrm{ws}}\right)$. As whole-stem thickness also includes xylem thickness, the difference between these measurements is the inner-bark radial thickness $\left(d_{\mathrm{b}}\right)$. Inner-bark thickness, hence, includes the cambium and the phloem tissue towards the outside of the cambium. Dendrometer measurements (accuracy $1 \mu \mathrm{m}$ ) at $30 \mathrm{~min}$ intervals were used for the study and were offset to zero on 1 April of each year.

We used the radial measurements to calculate a dimensionless ratio, $\beta$, which is the ratio of the change in $d_{\mathrm{x}}$ to the change in $d_{\mathrm{b}}$ (Eq. 4):

$\beta=\frac{d_{\mathrm{bMAX}}-d_{\mathrm{bMIN}}}{d_{\mathrm{xMAX}}-d_{\mathrm{xMIN}}}$,

where $d_{\mathrm{bMAX}}$ and $d_{\mathrm{bMIN}}$ correspond to the maximum and minimum daily inner-bark diameter, respectively, and $d_{\mathrm{xMAX}}$ and $d_{\mathrm{xMIN}}$ correspond to the maximum and minimum daily xylem diameter, respectively. This ratio is proportional to the ratio of the elasticity of the inner-bark tissues to xylem tissues. Note that an assumption is made here that the xylem and inner bark tend towards water potential equilibrium with each other at the minimum and maximum diameters. As the elasticity of the xylem tissue is dependent mainly on the elastic properties of the dead xylem tracheids (Irvine and Grace, 1997; Perämäki et al., 2001) and the xylem and inner bark (Sevanto et al., 2011) tend to approximately follow water potential equilibrium on a daily scale, the changes in $\beta$ represent mainly the changes in the elasticity of the phloem.

Sap flow rate was measured with the Granier-type heat dissipation method at a height of about $13 \mathrm{~m}$. Two probes, of $50 \mathrm{~mm}$ in length, were inserted in $2 \mathrm{~mm}$ wide brass cylinders into the sapwood approximately $10 \mathrm{~cm}$ apart. The upper probe (with $30 \Omega$ resistance) was heated with constant power (approximately $0.2 \mathrm{~W}$ ) and the sap flux density was calculated from the temperature difference between the two probes with a standard protocol (see, e.g., Granier, 1987). 
Air temperature was measured at $8 \mathrm{~m}$ height (Pt-100 sensor) and in soil A horizon $(5-10 \mathrm{~cm}$ depth with Philips thermistors). Precipitation was measured (Vector ARG-100 tipping bucket rain gauge and Vaisala FD12P weather sensor) in an open site at $30 \mathrm{~min}$ intervals. Snow depth was measured once a week at seven locations below canopies at the study site and averaged for the forest stand.

\section{Results}

Weather patterns in both springs were rather normal (Table 1). Mean temperatures in April were somewhat below the long-time average, but May temperatures were slightly higher. The onset of the growing period was typical for the site. The maximum depth of snow was in both years higher than average, but snow was melting slightly earlier than normal.

The emission measurements show that very early in spring, already in early April, significant monoterpene emissions from pine stem and shoot could be detected (Fig. 3). The emissions exhibited a clear diurnal cycle, with a maximum at midday and a minimum at midnight (Fig. 3a, b). Interestingly, a single, extremely high burst of monoterpene emission was observed from the stem in both years in April. At its highest, the monoterpene burst was 13 in 2012 and $50 \mathrm{ng} \mathrm{m}^{-2} \mathrm{~s}^{-1}$ in 2013. The corresponding normalized $\left(30^{\circ} \mathrm{C}\right)$ emissions in the bursts were 77 and $500 \mathrm{ng} \mathrm{m}^{-2} \mathrm{~s}^{-1}$, respectively. In 2012 , the peak occurred on 11 April, when the mean air temperature was $3.6^{\circ} \mathrm{C}$, and in 2013 on 19 April, when the mean air temperature was $3.4^{\circ} \mathrm{C}$. The average, temperature-normalized emission rate from the stem was $29 \mu \mathrm{g} \mathrm{m}^{-2} \mathrm{day}^{-1}$ after the burst in April-May 2012. In 2013, the normalized emission rates were $79 \mu \mathrm{g} \mathrm{m}^{-2}$ day $^{-1}$ before the burst in April and $47 \mu \mathrm{g} \mathrm{m}^{-2}$ day $^{-1}$ after the burst in April-May, respectively. In 2013, the mean measured monoterpene emission from the stem in April before the burst was $0.7 \mathrm{ng} \mathrm{m}^{-2} \mathrm{~s}^{-1}$ (standard deviation $0.6 \mathrm{ng} \mathrm{m}^{-2} \mathrm{~s}^{-1}$ ) and after the burst in April-May $1.3 \mathrm{ng} \mathrm{m}^{-2} \mathrm{~s}^{-1}$ (standard deviation $1.5 \mathrm{ng} \mathrm{m}^{-2} \mathrm{~s}^{-1}$ ).

The transient extremely high monoterpene emissions occurred after the freeze-thaw cycles, but their timing was different from the pre- and post-peak periods and varied slightly between years: in 2012, the highest values were measured in the afternoon, around 15:00 (all times in UTC+2), whereas in 2013 the highest values occurred in late evening, around 21:00 (Fig. 4a, b). In 2012, the high emissions were recorded for $12 \mathrm{~h}$, after which emissions returned to their normal, low levels. In 2013, the emission measurements were unfortunately interrupted due to a communication error between the PTR-MS and the laptop controlling it during the peak emission. Before the break, the high emissions had continued for $9 \mathrm{~h}$.

The stem monoterpene emission peaks in April did not coincide with the highest emission periods from shoots (Fig. 3).
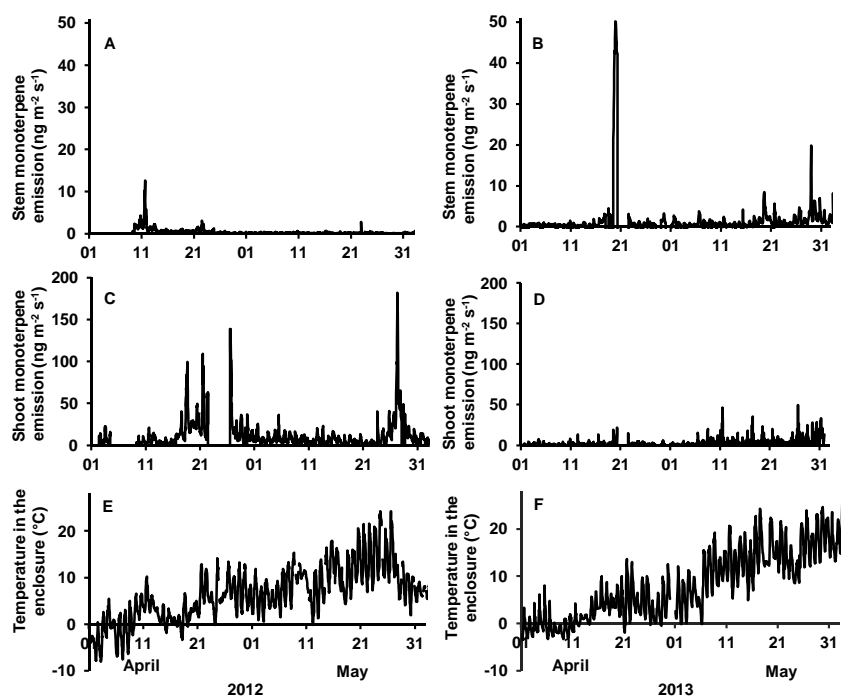

Figure 3. (a-b) Measured monoterpene emission $(\mathrm{m} / \mathrm{z}, 137$, $n \mathrm{n} \mathrm{m}^{-2}$ bark area s${ }^{-1}$ ) from the pine stem (same location on the stem in both years). (c-d) Measured monoterpene emission $\left(m / z 137, \mathrm{ng} \mathrm{m}^{-2}\right.$ total needle area $\left.\mathrm{s}^{-1}\right)$ from a pine shoot (same shoot in both years). (e-f) Temperature $\left({ }^{\circ} \mathrm{C}\right)$ in the stem enclosure. Left-hand panels for April-May 2012, right-hand panels for AprilMay 2013.

The stem and shoot monoterpene emissions were momentarily at about the same level during the stem monoterpene burst in 2012, but in 2013, the stem monoterpene emissions clearly exceeded those from the shoots.

The observed inner-bark radial thickness $\left(d_{\mathrm{b}}\right)$ dynamics were very different before, during and after the observed emission burst. Thus, we separated them into three consecutive phases. The first phase began in early April, when large and reversible stem swelling and shrinkage was observed, which was associated with repeated freeze-thaw cycles (Figs. 4 and 5). These freeze-thaw cycles were observed over the first 9 days of both Aprils, coinciding with daily minimum temperatures below $-5^{\circ} \mathrm{C}$.

The second phase began once monoterpene emission started. Immediately after the stem monoterpene emission burst ceased, a period lasting roughly 1 week was seen in $d_{\mathrm{b}}$ (Fig. 5a, b). Recovery of the $d_{\mathrm{b}}$ from the first period's freeze-thaw cycles was detected, which occurred roughly 3 days after the burst in 2012 and almost immediately in 2013. On 11-23 April 2012 and 19-25 April 2013, $d_{\mathrm{b}}$ and $d_{\mathrm{x}}$ were swelling and shrinking with no time lag, or even $d_{\mathrm{b}}$ swelling occurring before $d_{\mathrm{x}}$. We considered the end of the second phase to take place once the $d_{\mathrm{x}}$ and $d_{\mathrm{b}}$ changes got more regular. Thus, the stem and its water transport got acclimated to external factors such as rising air temperature.

In the third phase, a regular swelling and shrinking of the stem radius was observed: $d_{\mathrm{b}}$ followed $d_{\mathrm{x}}$ with a time lag. This kind of pattern is typical of the active growing period and is commonly observed in summertime at the study site. 

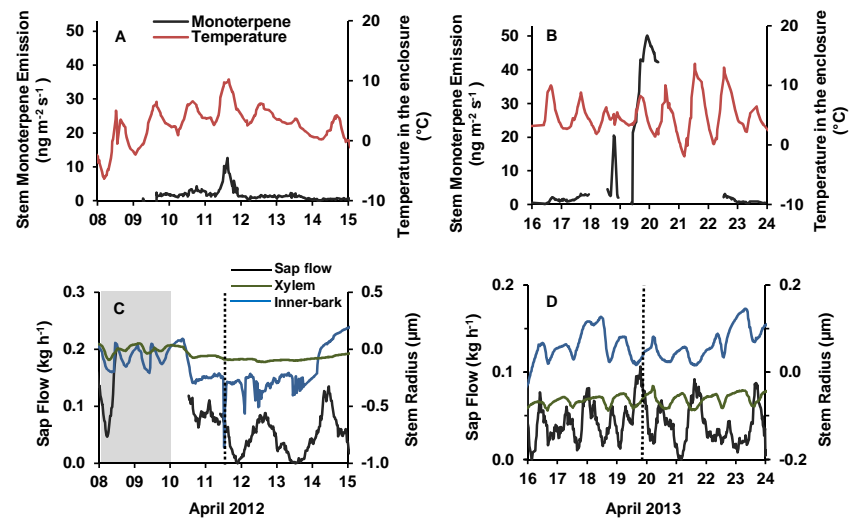

Figure 4. (a-b) Monoterpene emission from the stem $(\mathrm{m} / \mathrm{z} 137$, ng m${ }^{-2}$ bark area s$\left.{ }^{-1}\right)$ and the air temperature $\left({ }^{\circ} \mathrm{C}\right)$ inside the enclosure. (c-d) Stem sap flow $\left(\mathrm{kg} \mathrm{h}^{-1}\right)$ and inner-bark and xylem radius $(\mu \mathrm{m})$. Left-hand panels for April 2012 and right-hand panels for April 2013. The grey shading refers to the periods when the stem was frozen. The timing of the monoterpene burst is marked with dotted lines in the lower panels.

Moreover, an irreversible $d_{\mathrm{b}}$ increment (i.e., radial growth) began shortly after the second phase.

Sap flow decreased and minimum occurred about 10 days after the peaks in monoterpene emissions, and then began to increase steadily to summertime levels following a similar pattern in temperature (Fig. 6). Nighttime sap flow occurred concurrently with the stem monoterpene emission peaks (Fig. 4), which does not typically occur at any other time of the year at this site. In addition, shoot transpiration was very low during the 2012 emission peak, although VPD was high, indicating closed stomata (data not shown).

$\beta$, reflecting the changes of inner-bark to xylem maximum daily amplitude, showed large daily variations prior to the emission burst followed by a decline shortly after (Fig. 7). During the second phase, $\beta$ exhibited noticeably smaller but abrupt changes lasting 2-3 days. After this response period, $\beta$ reached a steady summer state.

The stem $\mathrm{CO}_{2}$ efflux anomalies, i.e., the part of the respiration value that is not explained by the regular response to temperature (Fig. 8), reveal that prior to the high monoterpene emission peak of both years, the stem $\mathrm{CO}_{2}$ efflux anomaly increased relative to the period before, or immediately after in 2012 (2013 measurements were missing at that period due to system problems). This suggests that in addition to regular maintenance respiration, $\mathrm{CO}_{2}$ was released from some storage or there were some $\mathrm{CO}_{2}$-producing processes occurring. This high $\mathrm{CO}_{2}$ efflux during the monoterpene peak is not associated with growth since radial growth was observed with the point dendrometers approximately 1 month later.
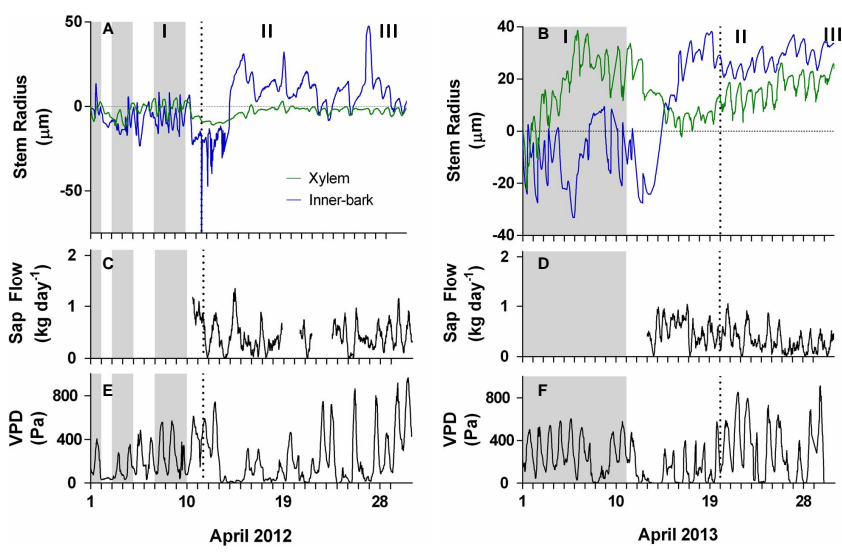

Figure 5. (a-b) Pine stem xylem and inner-bark radius changes $(\mu \mathrm{m})$. (c-d) Stem sap flow $\left(\mathrm{kg} \mathrm{day}^{-1}\right)$. (e-f) Vapor pressure deficit (VPD, Pa). Left-hand panels for April 2012 and right-hand panels for 2013. The grey shading refers to the periods when the stem was frozen. The timing of the monoterpene burst is marked with dotted lines. A closer look at the burst period is provided in Fig. 4. The Roman numerals refer to the three phases of inner-bark radial changes discussed in the text.

\section{Discussion}

We showed that in a boreal forest, monoterpenes are emitted from Scots pine stems continuously at a low rate in spring, with a systematic daily pattern - maxima in the afternoon and minima during nighttime. The stem monoterpene emissions differ from those measured from shoots in both magnitude and dynamics at the same time. The monoterpene emissions from Scots pine shoots show a clear seasonal pattern with several high transient emission periods in the beginning of the growing season (Aalto et al., 2014). The average level of the monoterpene emissions from the stem in springtime is in general lower than from the shoots (per area unit), which is likely due to lower oleoresin content and lower biological activity in the stem than in the shoots (Rockwood, 1973; Back and Ekman, 2000). The monoterpene emissions from the shoot were generally lower in 2013 than in 2012 (Fig. 3), but this is likely due to the aging of needles as the same shoot was enclosed in the measurement chamber in both years (Aalto et al., 2014). Moreover, the dynamics of the monoterpene emissions from the stem and shoots seem to be driven by different factors.

We compared the fluxes measured with chambers to those monitored with ecosystem-scale flux measurements (data not shown), but no clear correlations could be seen. Since the ecosystem-scale measurements upscale the emissions of the whole heterogenic stand, such transient physiological features related to emission changes in individual trees may not be observable at that scale. As the environmental factors vary within a forest stand and the tree individuals exhibit naturally somewhat different responses to these factors, there is vari- 


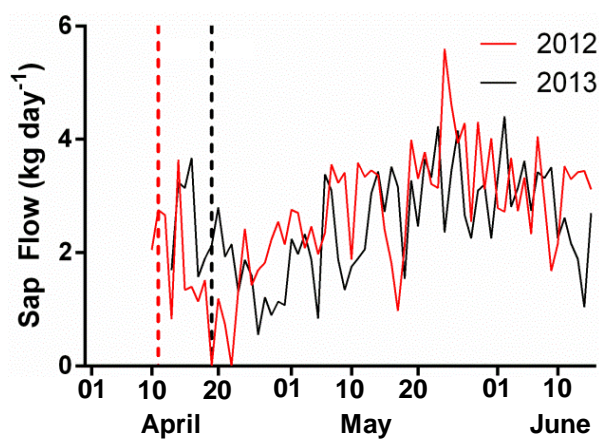

Figure 6. The daily sum of pine stem sap flow in 2012 (red) and 2013 (black). The timings of the monoterpene bursts are marked with dashed lines. The days when the stem was frozen are removed from the figure.

ance in the timing of the physiological processes within a stand.

In addition to the continuous low monoterpene emissions from the stem, we observed a rapid but large emission burst, lasting for several hours, after which the emissions decreased to the pre-burst levels, with a gradual emission increase towards summer concurrently with increasing ambient temperatures. The monoterpene emission burst coincided well with the recovery of stem radius from winter conditions. In both years studied, the burst occurred shortly after the last freezing period (Fig. 5). Around the time of the burst, stem radius fluctuations showed irregular behavior in comparison to the regular pattern observed during summer conditions, more noticeably in 2012. This behavior included inner-bark fluctuations occurring before xylem fluctuations, both inner-bark and xylem changes occurring concomitantly and large daily fluctuations unlike summertime behavior. In both years, the inner-bark radius had a depression relative to xylem around the emission burst, but extremely so during 2012. This behavior also coincided well with the changes in relative barkxylem daily amplitude, $\beta$, where the largest changes were seen shortly before the burst (Fig. 7), and also more prominent in the year 2012 when the bark shrinking was more pronounced. Also, the dynamics of sap flow behaved in a similar manner relative to the burst event on both years (Fig. 6). This irregular behavior relative to timing and amplitudes of xylem and inner bark indicates that driving forces other than transpiration, the main driver of diameter change variation during summer (Perämäki et al., 2001, 2005), drive the pattern of diameter change variation.

It is commonly known that freeze-thaw cycles experienced during winter cause winter embolism in trees (Sperry, 1993; Sperry and Robson, 2001; Pittermann and Sperry, 2006): frozen gases (mostly air and $\mathrm{CO}_{2}$ ) dissolve in xylem sap forming bubbles, which then expand during thawing and embolize the water-conducting tracheids. In spring, xylem conduits are refilled with water by metabolic processes that are not yet fully understood, but most likely involve the in-
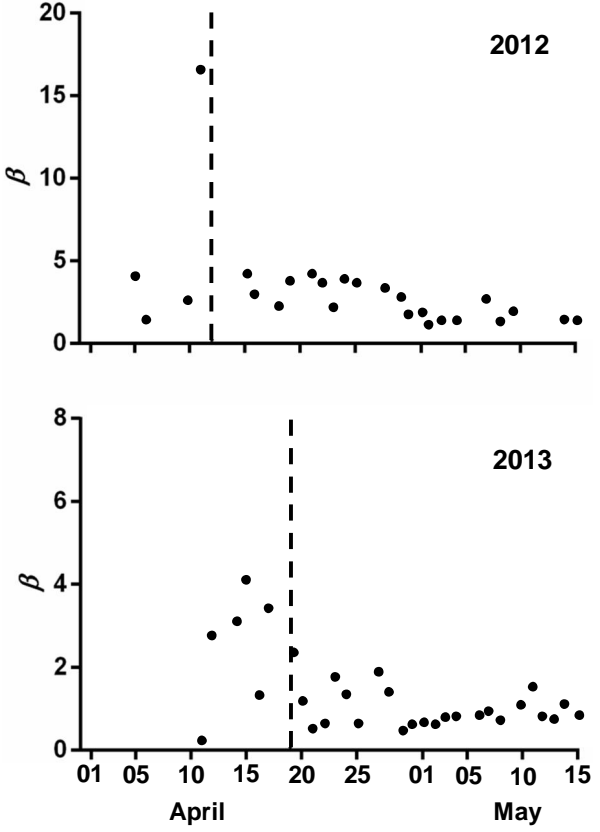

Figure 7. $\beta$ as a function of time in 2012 and 2013. The figure shows that $\beta$ (see Eq. 1), i.e., the daily amplitude of the phloem vs. xylem radial change, had its maximum value briefly before and during the monoterpene emission burst (dashed line). Days with occurrences of rain and frozen stem were removed.

teraction of living cells and radial interaction between xylem and phloem (Zwienieki and Holbrook, 2009; Nardini et al., 2011), resulting in the recovery of xylem transport capacity along with transpiration-driven tension propagation in stems. Cochard et al. (2001) demonstrated that an active mechanism for the recovery of shoot hydraulic conductivity via embolism refilling occurred early in the growing season, before cambial reactivation (i.e., before ring development). Also, aquaporin activity, which changes the permeability of the cell membranes, is known to be associated with embolism refilling (e.g., Sakr et al., 2003; Brodersen and McElrone, 2013).

Studies have shown that the inner bark (i.e., phloem) plays a contributory role by providing the mechanism to drive radial water flow, ultimately aiding osmotic flow into embolized conduits (Salleo et al., 1996; Zwieniecki et al., 2000; Salleo et al., 2004). Also, our results show that soon after the cessation of freeze-thaw events there occur changes, such as temporary shrinking of inner bark relative to xylem and high inner-bark vs. xylem amplitude changes, which could suggest an active role of phloem in xylem recovery. Also, the stem $\mathrm{CO}_{2}$ flux anomalies might be related to this phloem activity during embolism refilling, as embolism refilling is known to require input of energy (Zwieniecki and Holbrook, 2009). After this period, changes in stem radius achieved a general summertime steady state, where changes in inner bark follow xylem changes with a $30-45$ min time lag (Sevanto et al., 2002). 


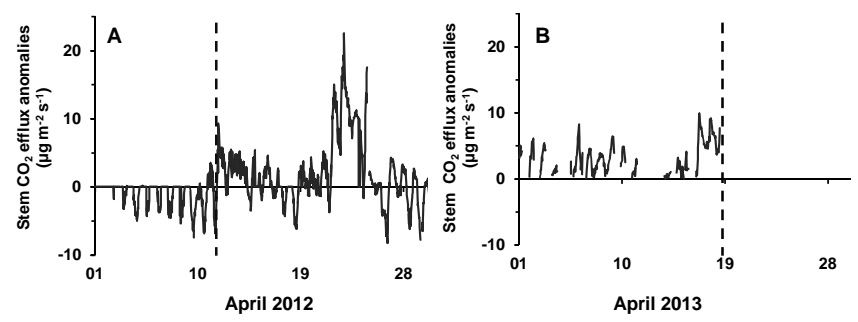

Figure 8. Temperature-corrected stem $\mathrm{CO}_{2}$ efflux anomalies for April 2012 (a) and 2013 (b).

The simultaneous dynamic changes in stem radius and deviation of xylem sap flow from normal conditions indicate that the changes in stem water relations are at least coinciding with if not causing the emission bursts in April. In addition to water transport, the shrinking and swelling of phloem could indicate the onset of growth: xylem microcore samples have indicated that xylem cells start forming at our measurement site after mid-May (Jyske et al., 2014) and phloem cells have been reported to start to form about 10 to 20 days before xylem cells in Scots pine (Antonova and Stasova, 2006). Thus, the timing of tree growth does not explain the observed bursts that were seen to occur prior to growth onset, and we need to search for explanations from other physical and physiological processes.

The most plausible causes of these transient monoterpene bursts from pine stem are volatilization from storages due to temperature increase (e.g., Lerdau et al., 1997), changes in the non-specific storage of monoterpenes (e.g., Niinemets and Reichstein, 2002), or a rapid pressure-induced mobilization of volatiles from resin ducts.

As volatile cues are important for many herbivores in finding their host trees, the springtime monoterpene emission dynamics may also be linked to tree-herbivore relations.

\subsection{Direct effect of temperature}

Monoterpene volatilization is a temperature-driven process (Guenther et al., 1993; Guenther, 1997; Lerdau et al., 1997; Tarvainen et al., 2005) and thus the seasonality of monoterpene emissions from vegetation is often linked to changes in ambient temperatures. Temperature-dependent emissions are especially important in species with large storage pools, such as conifers (e.g., Lewinsohn et al., 1991; Lerdau et al., 1997). The accumulation of monoterpenes in stem storage pools over winter and their release due to higher temperatures in spring could possibly lead to high emission rates. However, we could not identify any extraordinary weather conditions that could have caused such high emission peaks. The emission burst had in both years almost similar timing compared to the growing season: the burst took place on 11 April in 2012 and on 19 April in 2013 (onset of growing season 12 April and 16 April, respectively). Also, the daily mean temperatures of the peak emissions days were almost identical in both years.

The bark surface temperature follows ambient air temperature with a short time lag, but may occasionally rise well above ambient temperature due to direct irradiation on the bark surface. However, inside and especially below the canopy this happens only occasionally and only on one side of the stem at a time, and especially deeper inside the stem the response to changes in ambient temperatures is very slow. Measurements on a $60 \mathrm{~cm}$ thick Monterey pine have shown that the diurnal temperature range inside the stem is only about one-third of the range in ambient air (Neher, 1993). Thus, the oleoresin-rich heartwood (Strömvall and Petersson, 2000) stays in more stable conditions than the sapwood with lower oleoresin content. On the other hand, sapwood includes the living cells of the xylem and thus its temperature changes might be more significant for monoterpene emissions, especially in the case of de novo emissions. Our stem enclosure was situated inside the living canopy, so there apparently was only living sapwood and no heartwood enclosed.

It is also possible that the monoterpenes get reallocated from roots to upper tree parts through sap flow. However, as oleoresin is still rather viscous at the prevailing temperatures in spring, and the monoterpenes do not easily dissolve in water, this may not provide a good explanation for the observed peak emissions.

\subsection{Changes in non-specific storage of monoterpenes due to changes in membrane permeability during spring}

The spring dehardening involves many biochemical changes affecting membrane transport properties and changing membrane permeability (Pukacki and Kaminska-Rozek, 2013; Martz et al., 2006), which likely also influence the water relations in stem and xylem refilling. Changes in membrane properties (e.g., elasticity and permeability) were likely seen as changes in stem radius measured with point dendrometers. The change in permeability is reflected in the water status of the living cells of the stem, affecting sap flow rate as well.

A dynamic, non-specific monoterpene storage pool exists in cellular membranes (Niinemets and Reichstein, 2002, 2003a, b; Ormeño et al., 2011). This pool may either influence or be affected by membrane permeability changes. At high concentrations, monoterpenes may alter the properties of membrane proteins (Wink, 2003) and thus also affect the permeability and other bioactive features of the membrane. Monoterpenes may affect membrane permeability and cause leakage of intracellular materials of pathogenic microbes, which could explain their antimicrobial activity (Trombetta et al., 2005; Cristani et al., 2007). Since the properties of cell membranes change dramatically during dehardening, this may lead to a release of membrane-accumulated monoterpenes - however, it is unlikely that the release would be seen 
as such a short and transient emission peak, but rather as a gradually increasing emission rate as the dehardening proceeds.

\subsection{A rapid mobilization of volatiles from resin ducts}

A rather plausible explanation for the monoterpene emission peaks is a pressure-induced release of volatiles from resin duct cavities. Resin ducts are located both horizontally and vertically in the stem, and thus they are in contact with both heartwood and sapwood. It is likely that the rapid changes in water transport and related pressure changes in stem in spring could lead to a pressure change in the xylem resin ducts and a consequent release of oleoresin. Such an effect could be corresponding to a damage-induced, transient release of monoterpenes from herbivory or mechanical wounding. However, after a steady diurnal water transport rate is obtained (in some hours after the recovery of the xylem), the resin ducts no longer experience strong pressure effects and emissions go down to a "normal" diurnal pattern.

Monoterpene emissions may also originate from the gases inside embolized tracheids. It is well known that a large proportion of tracheids is embolized during the winter as gas bubbles get trapped inside the frozen xylem sap during freezing and expand to embolize the tracheids during thawing (e.g., Pittermann and Sperry, 2003). The air inside the embolized tracheids may have a high concentration of monoterpenes, as the turnover rate of the gases is low and monoterpenes can diffuse to tracheids from the neighboring resin ducts over the winter. Once the conduits refill with water in the spring, the gases, including monoterpenes, within the embolized tracheids diffuse out from the stem (Yang and Tyree, 1992; Vesala et al., 2003). It is unclear how large the changes in stem gas content are during the spring, and whether monoterpene concentrations can be high enough to sustain a burst for several hours. However, substantial changes in the volume of gas inside the stem are very likely, as the volumetric water content of the stem is known to vary a lot during winter months (Sparks et al., 2001) and can increase by up to tens of percents during the springtime (Wullschleger et al., 1996). On the other hand, once the embolized tracheid cells fill up with water in spring, the filling causes extra pressure on resin ducts, and this may also cause micro-scale damages on the ducts followed by a subsequent oleoresin flow and elevated monoterpene emissions.

\section{Conclusions}

Although emission measurements on tree shoots using branch enclosures abound, very little is known about the emission patterns and their driving factors of the woody parts of the shoots. This study is the first to show that monoterpene emissions from Scots pine stems are linked to changes in stem water relations during the spring recovery. The stem emissions seem to be less related to changes in incident changes in environment than to the physiology of the tree, especially during the winter dehardening phase. The dynamic changes in stem processes (irregular diurnal pattern of stem radial change, nighttime sap flow, and transient monoterpene burst) indicate a springtime phase change in stem water transport capacity that precedes the physiologically active summer state of the tree. After this period, the water transport capacity reaches a steady summer state with stable daily patterns of stem radial change and sap flow rates. While the emission dynamics in foliage follows a clear temperature and light dynamics, the large oleoresin reservoirs in woody compartments seem to be less directly affected by these incident factors, and rather reflect a longer-term adjustment of the whole tree physiology. The large transient emission peaks from stem are most likely related to the springtime refilling of embolized tracheids. Future studies on the topic could address the cellular-level processes in tree stems, and their connections to seasonal water transport capacity and occurrence of insect outbreaks.

Acknowledgements. This work was supported by the Finnish Center of Excellence "Physics, Chemistry, Biology and Meteorology of Atmospheric Composition and Climate Change" (projects 1118615 and 272041), the Nordic Center of Excellence CRAICC and the Helsinki University Centre for Environment HENVI. We highly acknowledge the assistance given during the measurements by the staff of the SMEAR II station.

Edited by: M. Glasius

\section{References}

Aalto, J., Kolari, P., Hari, P., Kerminen, V.-M., Schiestl-Aalto, P., Aaltonen, H., Levula, J., Siivola, E., Kulmala, M., and Bäck, J.: New foliage growth is a significant, unaccounted source for volatiles in boreal evergreen forests, Biogeosciences, 11, 13311344, doi:10.5194/bg-11-1331-2014, 2014.

Altimir, N., Kolari, P., Tuovinen, J.-P., Vesala, T., Bäck, J., Suni, T., Kulmala, M., and Hari, P.: Foliage surface ozone deposition: a role for surface moisture?, Biogeosciences, 3, 209-228, doi:10.5194/bg-3-209-2006, 2006.

Améglio, T., Bodet, C., Lacointe, A., and Cochard, H.: Winter embolism, mechanisms of xylem hydraulic conductivity recovery and springtime growth patterns in walnut and peach trees, Tree Physiol., 22, 1211-1220, 2002.

Antonova, G. F. and Stasova, V. V.: Seasonal development of phloem in Scots pine stems, Ontogenez, 37, 368-383, 2006.

Back, E. L. and Ekman, R.: The variability of wood resin, in: Pitch control, wood resin and deresination, edited by: Back, E. L. and Allen, L. H., TAPPI Press, Atlanta, pp. xii-xiv, 2000.

Brodersen, C. R. and McElrone, A. J.: Maintenance of xylem network transport capacity: a review of embolism repair in vascular plants, Front. Plant Sci., 4, 1-11, 2013.

Christensen, C. S., Hummelshøj, P., Jensen, N. O., Larsen, B., Lohse, C., Pilegaard, K., and Skov, H.: Determination of terpene 
flux from orange species and Norway spruce by relaxed eddy accumulation, Atmos. Environ., 34, 3057-3067, 2000.

Cochard, H., Lemoine, D., Améglio, T., and Granier, A.: Mechanisms of xylem recovery from winter embolism in Fagus sylvatica, Tree Physiol., 21, 27-33, 2001.

Cristani, M., D’Arrigo, M., Mandalari, G., Castelli, F., Sarpietro, M. G., Micieli, D., Venuti, V., Bisignano, G., Saija, A., and Trombetta, D.: Interaction of four monoterpenes contained in essential oils with model membranes: implications for their antibacterial activity, J. Agric. Food Chem., 55, 6300-6308, 2007.

Erbilgin, N. and Colgan, L. J.: Differential effects of plant ontogeny and damage type on phloem and foliage monoterpenes in jack pine (Pinus banksiana), Tree Physiol., 32, 946-957, 2012.

Ghirardo, A., Koch, K., Taipale, R., Zimmer, I., Schnitzler, J.-P., and Rinne, J.: Determination of de novo and pool emissions of terpenes from four common boreal/alpine trees by ${ }^{13} \mathrm{CO}_{2}$ labelling and PTR-MS analysis, Plant Cell Environ., 33, 781-792, 2010.

Grabmer, W., Graus, M., Wisthaler, A., Rappenglück, B., Steinbrecher, R., and Hansel, A.: Disjunct eddy covariance measurements of monoterpene fluxes from a Norway spruce forest using PTR-MS, Int. J. Mass Spectrom., 239, 111-115, 2004.

Granier, A.: Evaluation of transpiration in a Douglas-fir stand by means of sap flow measurements, Tree Physiol., 3, 309-320, 1987.

Granström, K. M.: Wood processing as a source of terpene emissions compared to natural sources, WIT Trans. Ecol. Envir., 101, 263-272, 2007.

Guenther, A.: Seasonal and spatial variations in natural volatile organic compound emissions, Ecol. Appl., 7, 34-45, 1997.

Guenther, A., Zimmerman, P., Harley, P., Monson, R., and Fall, R.: Isoprene and monoterpene emission rate variability: model evaluations and sensitivity analyses, J. Geophys. Res., 98, 1260912617, 1993.

Hakola, H., Tarvainen, V., Bäck, J., Ranta, H., Bonn, B., Rinne, J., and Kulmala, M.: Seasonal variation of mono- and sesquiterpene emission rates of Scots pine, Biogeosciences, 3, 93-101, doi:10.5194/bg-3-93-2006, 2006.

Hansel, A., Jordan, A., Holzinger, R., Prazeller, P., Vogel, W., and Lindinger, W.: Proton transfer reaction mass spectrometry: online trace gas analysis at ppb level, Int. J. Mass Spectrom., 149, 609-619, 1995.

Hari, P. and Kulmala M.: Station for measuring EcosystemAtmosphere Relations (SMEAR II), Boreal Environ. Res., 10, 315-322, 2005.

Irvine, J. and Grace, J.: Continuous measurements of water tensions in the xylem of trees based on the elastic properties of wood, Planta, 202, 455-461, 1997.

Isidorov, V. A., Zenkevich, I. G., and Ioffe, B.V.: Volatile organic compounds in the atmosphere of forests, Atmos. Environ., 19, $1-8,1985$.

Jyske, T., Mäkinen, H., Kalliokoski, T., and Nöjd, P.: Intra-annual tracheid production of Norway spruce and Scots pine across a latitudinal gradient in Finland, Agric. For. Meteorol., 194, 241254, 2014.

Keronen, P., Reissell, A., Chevallier, F., Siivola, E., Pohja, T., Hiltunen, V., Hatakka, J., Aalto, T., Rivier, L., Ciais, P., Jordan, A., Hari, P., Viisanen, Y., and Vesala, T.: Accurate measurements of $\mathrm{CO}_{2}$ mole fraction in the atmospheric surface layer by an affordable instrumentation, Boreal Environ. Res., 19, 35-54, 2014.
Kolari, P., Kulmala, L., Pumpanen, J., Launiainen, S., Ilvesniemi, H., Hari, P., and Nikinmaa, E.: $\mathrm{CO}_{2}$ exchange and component $\mathrm{CO}_{2}$ fluxes of a boreal Scots pine forest, Boreal Environ. Res., 14, 761-783, 2009.

Kolari, P., Bäck, J., Taipale, R., Ruuskanen, T. M., Kajos, M. K., Rinne, J., Kulmala, M., and Hari, P.: Evaluation of accuracy in measurements of VOC emissions with dynamic chamber system, Atm. Env., 62, 344-351, 2012.

Langenheim, J. H.: Plant resins: chemistry, evolution, ecology, and ethnobotany, Timber Press, Portland, Cambridge, 586 pp., 2003.

Lerdau, M., Litvak, M., Palmer, P., and Monson, R.: Controls over monoterpene emissions from boreal forest conifers, Tree Physiol., 17, 563-569, 1997.

Lewinsohn, E., Gijzen, M., and Croteau, R.: Defence mechanisms of conifers, Plant Physiol., 96, 44-49, 1991.

Loreto, F., Ciccioli, P., Brancaleoni, E., Cecinato, A., Frattoni, M., and Sharkey, T. D.: Different sources of reduced carbon contribute to form three classes of terpenoid emitted by Quercus ilex L. leaves, P. Natl. Acad. Sci. USA, 93, 9966-9969, 1996.

Martz, F., Sutinen, M.-L., Kiviniemi, S., and Palta, J. P.: Changes in freezing tolerance, plasma membrane $\mathrm{H}^{+}$-ATPase activity and fatty acid composition in Pinus resinosa needles during cold acclimation and de-acclimation, Tree Physiol., 26, 783-790, 2006.

Mencuccini, M., Hölttä, T., Sevanto, S., and Nikinmaa, E.: Concurrent measurements of change in the bark and xylem diameters of trees reveal a phloem-generated turgor signal, New Phytol., 198, 1143-1154, 2013.

Nardini, A., Lo Gullo, M. A., and Salleo, S.: Refilling embolized xylem conduits: is it a matter of phloem unloading?, Plant Sci., 180, 604-611, 2011.

Neher, H. V.: Effects of pressures inside Monterey pine trees, Trees, 8, 9-17, 1993.

Niinemets, Ü. and Reichstein, M.: A model analysis of the effects of nonspecific monoterpenoid storage in leaf tissues on emission kinetics and composition in Mediterranean sclerophyllous Quercus species, Global Biogeochem. Cy., 16, 1-26, 2002.

Niinemets, Ü. and Reichstein, M.: Controls on the emission of plant volatiles through stomata: Differential sensitivity of emission rates to stomatal closure explained, J. Geophys. Res., 108, 4208, doi:10.1029/2002JD002620, 2003a.

Niinemets, Ü. and Reichstein, M.: Controls on the emission of plant volatiles through stomata: A sensitivity analysis, J. Geophys. Res., 108, 4211, doi:10.1029/2002JD002626, 2003 b.

Ormeño, E., Goldstein, A., and Niinemets, Ü.: Extracting and trapping biogenic volatile organic compounds stored in plant species, Trends Analyt. Chem., 30, 978-989, 2011.

Perämäki, M., Vesala, T., and Nikinmaa, E.: Analysing the applicability of the heat balance method for estimating sap flow in boreal forest conditions, Boreal Environ. Res., 6, 29-43, 2001.

Perämäki, M., Vesala, T., and Nikinmaa, E.: Modeling the dynamics of pressure propagation and diameter variation in tree sapwood, Tree Physiol., 25, 1091-1099, 2005.

Phillips, M. A. and Croteau, R. B.: Resin-based defences in conifers, Trends Plant Sci., 4, 184-190, 1999.

Pirinen, P., Simola, H., Aalto, J., Kaukoranta, J.-P., Karlsson, P., and Ruuhela, R.: Tilastoja Suomen ilmastosta 1981-2010, Finnish Meteorological Inst. Rep. 2012/1, 1-96, 2012. 
Pittermann, J. and Sperry, J.: Tracheid diameter is the key trait determining the extent of freezing-induced embolism in conifers, Tree Physiol., 23, 907-914, 2003.

Pittermann, J. and Sperry, J. S.: Analysis of freeze-thaw embolism in conifers. The interaction between cavitation pressure and tracheid size, Plant Physiol., 140, 374-382, 2006.

Pukacki, P. M. and Kaminska-Rozek, E.: Differential effects of spring reacclimation and deacclimation on cell membranes of Norway spruce seedlings, Acta Soc. Bot. Pol., 82, 77-84, 2013.

Rockwood, D. L.: Variation in the monoterpene composition of two oleoresin systems of loblolly pine, Forest Sci., 19, 147-153, 1973.

Ruuskanen, T. M., Kolari, P., Bäck, J., Kulmala, M., Rinne, J., Hakola, H., Taipale, R., Raivonen, M., Altimir, N., and Hari, P.: On-line field measurements of monoterpene emissions from Scots pine by proton transfer reaction - mass spectrometry, Boreal Environ. Res., 10, 553-567, 2005.

Sakr, S., Alves, G., Morillon, R., Maurel, K., Decourteix, M., Guilliot, A., Fleurat-Lessard, P., Julien, J.-L., and Chrispeels, M. J.: Plasma membrane aquaporins are involved in winter embolism recovery in walnut tree, Plant Physiol., 133, 630-641, 2003.

Salleo, S., Lo Gullo, M. A., DePaoli, D., and Zippo, M.: Xylem recovery from cavitation-induced embolism in young plants of Laurus nobilis: a possible mechanism, New Phytol., 132, 47-56, 1996.

Salleo, S., Lo Gullo, M. A., Trifilo, P., and Nardini, A.: New evidence for a role of vessel-associated cells and phloem in the rapid xylem refilling of cavitated stems of Laurus nobilis L., Plant Cell Environ., 27, 1065-1076, 2004.

Sevanto, S., Vesala, T., Perämäki, M., and Nikinmaa, E.: Time lags for xylem and stem diameter variations in a Scots pine tree, Plant Cell Environ., 25, 1071-1077, 2002.

Sevanto, S., Hölttä, T., Markkanen, T., Perämäki, M., Nikinmaa, E., and Vesala, T.: Relationships between diurnal xylem diameter variation and environmental factors in Scots pine, Boreal Environ. Res., 10, 447-458, 2005.

Sevanto, S., Hölttä, T., and Holbrook, N. M.: Effects of the hydraulic coupling between xylem and phloem on diurnal phloem diameter variation, Plant Cell Environ., 34, 690-703, 2011.

Shao, M., Czapiewski, K.V., Heiden, A. C., Kobel, K., Komenda, M., Koppmann, R., and Wildt, J.: Volatile organic compound emissions from Scots pine: mechanisms and description by algorithms, J. Geophys. Res., 106, 20483-20491, 2001.

Sparks, J. P., Campbell, G. S., and Black, R. A.: water content, hydraulic conductivity, and ice formation in winter stems of Pinus contorta: a TDR case study, Oecologia, 127, 468-475, 2001.

Sperry, J. S.: Winter xylem embolism and spring recovery in Betula cordifolia, Fagus grandifolia, Abies balsamea and Picea rubens, in: Water Transport in Plants under Climatic Stress, edited by: Borghetti, M., Grace, J., Raschi, A., Cambridge University Press, Cambridge, UK, 86-98, 1993.
Sperry, J. S. and Robson, J. D.: Xylem cavitation and freezing in conifers, in: Conifer cold hardiness, edited by: Bigras, F. J. and Colombo, S., Springer, Netherlands, 121-136, 2001.

Staudt, M. and Bertin, N.: Light and temperature dependence of the emission of cyclic and acyclic monoterpenes from holm oak (Quercus ilex L.) leaves, Plant Cell Environ., 21, 385-395, 1998.

Strömvall, A.-M. and Petersson, G.: Conifer monoterpenes emitted to air by logging operations, Scand. J. For. Res., 6, 253-258, 1991.

Strömvall, A.-M. and Petersson, G.: Monoterpenes emitted to air from industrial barking of Scandinavian conifers, Environ. Pollut., 79, 215-218, 1993.

Strömvall, A.-M. and Petersson, G.: Volatile terpenes emitted to air, in: Pitch control, wood resin and deresination, edited by: Back, E. L. and Allen, L. H., TAPPI Press, Atlanta, 77-99, 2000.

Tarvainen, V., Hakola, H., Hellén, H., Bäck, J., Hari, P., and Kulmala, M.: Temperature and light dependence of the VOC emissions of Scots pine, Atmos. Chem. Phys., 5, 989-998, doi:10.5194/acp-5-989-2005, 2005.

Tingey, D. T., Manning, M., Grothaus, L. C., and Burns, W. F.: Influence of light and temperature on monoterpene emission rates from slash pine, Plant Physiol., 65, 797-801, 1980.

The Finnish Meteorological Institute Open Data: https://en. ilmatieteenlaitos.fi/open-data, last access: 19 February 2014.

The Finnish Meteorological Institute, Climate in Finland: http://en. ilmatieteenlaitos.fi/climate, last access: 12 February 2014.

Trapp, S. and Croteau, R.: Defensive resin biosynthesis in conifers, Annu. Rev. Plant Physiol. Plant. Mol. Biol., 52, 689-724, 2001.

Trombetta, D., Castelli, F., Sarpietro, M. G., Venuti, V., Cristani, M., Daniele, C., Saija, A., Mazzanti, G., and Bisignano, G.: Mechanisms of antibacterial action of three monoterpenes, Antimicrob. Agents Chemother., 49, 2474-2478, 2005.

Vesala, T., Hölttä, T., Perämäki, M., and Nikinmaa, E.: Refilling of a hydraulically isolated embolized xylem vessel: model calculations, Ann. Bot., 91, 419-428, 2003.

Wink, M.: Evolution of secondary metabolites from an ecological and molecular phylogenetic perspective, Phytochemistry, 64, 3 19, 2003.

Wullschleger, S. D., Hanson, P. J., and Todd, D. E.: Measuring stem water content in four deciduous hardwoods with a time-domain reflectometer, Tree Physiol., 16, 809-815, 1996.

Yang, S. and Tyree, M. T.: A theoretical model of hydraulic conductivity recovery from embolism with comparison to experimental data on Acer saccharum, Plant Cell Environ., 15, 633-643, 1992.

Zwieniecki, M. A., Hutyra, L., Thompson, M. V., and Holbrook, N. M.: Dynamic changes in petiole specific conductivity in red maple (Acer rubrum L.), tulip tree (Liriodenron tulipifera L.) and northern fox grape (Vitis labrusca L.), Plant Cell Environ., 23, 407-414, 2000.

Zwieniecki, M. A. and Holbrook, N. M.: Confronting Maxwell's demon: biophysics of xylem embolism repair, Trends Plant Sci., 14, 530-534, 2009. 